\title{
THE IMPACT OF E-LEARNING ON IMPROVING IRANIAN EFL LEARNERS' LANGUAGE SKILLS: DECREASING LEARNING ANXIETY
}

\author{
M. A. Jahansouz Shahi
}

Department of English Teaching, Najaf Abad Branch, Islamic Azad University, Najaf Abad, Iran

Published online: 15 May 2016

\begin{abstract}
Multimedia materials in the English classroom play a novel role in language learning. The report presents the advantages of the e-learning and its role in enhancing "English Foreign language" (EFL) students' language skills and independent learning. An already running and established virtual learning environment, namely the e-learning, was used successfully in the Azad University in Iran. Participants in this study were of EFL (English as a Foreign language) university students majoring in computer engineering and IT (information technology). A pretest and posttest included listening, reading comprehension and grammatical points contain multiple choices, fill in the blank, substitution, written form. Two classes were randomly selected as a control group and experimental group in the study. The different activities and resources that were provided by e-learning have been described with an analysis of how they can be used to develop EFL students' language proficiency and independent learning. The purpose of this study was to expose a group of Iranian students to an e-learning program and find out the effects of this exposure on their learning skills. The study conducted claims to identify and understand the relationship between multimedia techniques in language teaching and learners' language learning. Its results also suggest that a multimedia environment can reduce student anxiety and provide a less stressful classroom environment.
\end{abstract}

Author Correspondence, e-mail: authorC@ gmail.com

doi: http://dx.doi.org/10.4314/jfas.v8i3s.180

Journal of Fundamental and Applied Sciences is licensed under a Creative Commons Attribution-NonCommercial 4.0 International License. Libraries Resource Directory. We are listed under Research Associations category. 
Put otherwise, multimedia tools enable English teachers to help students to both improve their English performance and lower their language anxiety.

Keywords: CALL; E-Learning; English as a Foreign Language ( EFL ); Scaffolding.

\section{INTRUDUCTION}

\section{Theoretical framework}

The first factor which is involved to this research is e-Learning. It was defined by many researchers. Waterhouse (2003) defined it as a medium of computer technology that could be utilized to develop the application of learning and teaching. Moreover, The European Commission (2001) defines e-learning as "the use of new multimedia technologies and the internet to improve the quality of learning by facilitating access to resources and services as well as remote exchanges and collaboration”. Using a narrower concept, Rosenberg (2001) stated that e-learning permits data saving, sharing and updating while Horton (2006) believes that e-learning allows the building up of "learning experiences of information and computer technology". It is important to note that all definitions agree to the fact that e-learning involves using computer technology to facilitate and enhance learning.

The growing use of online technologies for teaching and learning is renewing the demand for better understanding of student characteristics that affect learning and the effective design of online instruction. The invention and use of computers has had tremendous impact on various aspects of scientific study. "Computers, which were primarily used for mathematical concerns at its birth, have had their unique place in every part of our lives. Soon afterwards they started to be utilized in general education especially in language learning, and the term „Computer-Assisted Language Learning (CALL), referring to the use of computers in the learning and teaching of English, appeared in the literature in early 1970s" (Karakash and Ersoy, 2011, p.40).

CALL plays an important role in teaching that focuses on interaction, and individualized teaching. CALL can make up for the shortcomings of traditional one-way teaching methods, replacing it with two-way language teaching. The benefits of CALL are that it can combine text, sound effects and images in order to increase the diversity of teaching and to promote learning efficiency by inspiring students' learning desire. A previous study by Hwang (2010) highlights the advantages of CALL as follows:

1. CALL can increase the learning effect by facilitating the repetition of learning exercises. 
2. CALL can make study more interesting, enhancing students' learning desire.

3. CALL can achieve the goal of applied English learning through simulated teaching content.

4. CALL provides assistance and lesson content that learners can help themselves too.

In other words, the CALL can increase the opportunities for interaction, individualize learning, generate immediate feedback, encourage students to learn actively and monitor students learning conditions easily.

Despite the benefits that have been reported in the literature on online teaching, there are also other issues that have been identified in relation to online teaching, particularly about online learners. Recent literature on e-Learning indicates that not all students perform successfully in online courses. This may be caused by factors related to the learning environment and/or personal characteristics. Research reports have indicated that student success is influenced by factors such as learning styles (Diaz \& Cartnal, 1999 ; Gagne, Briggs \& Wager1992; Terrell \& Dringus, 2000; Zhang \& Sternberg, 2001), self-directive competencies (Birch, 2002), and motivation (Pintrich \& Schunk, 2002). Identifying learner characteristics for successful online experience was reported to serve the best interest of students (Wojciechowski \& Palmer 2005) and should be part of any systematic design of instruction (Dick \& Carey, 1996). Based on these findings, we have been conducting surveys of learners ${ }^{\text {ee }}$ attitude since 2005, and have reported initial findings on learner characteristics as factors affecting student performance in hybrid courses (Nakayama et al., 2006).

CALL has played an important role in personalizing education. The recent advances in educational applications of computer hardware and software have provided a rapidly growing resource for language classrooms. The practical applications of Computer Assisted Language Learning (CALL) are growing at such a rapid pace that it is almost impossible for a classroom teacher to keep up with the field. This growth is quite justifiable in terms of educational advantages it offers particularly the availability of rich resources for both learners and teachers and the increased possibility of web-based interaction as a source for further learning. As Roger (1996, cited in Lai, 2006) states, when the computer is used in conjunction with traditional second language classroom study, students can study more independently, leaving the teacher more time to concentrate on those parts of second language teaching that are still hard or impossible by computer. Owing to such pedagogical benefits, computer technology has become more accessible to both individuals and schools and the growing understanding of its potentials 
has encouraged a shift of emphasis away from computer technology itself to various application of such technology in more practical aspects of teaching and learning.

Benson and Voller(1997, cited in Carter and Nunan,2002) states that: The widespread availability of audio tape, videotape, CD-Roms, DVDs, educational software and internet downloads of sound and video files has vastly increased potential input material for language learning. Consequently, selection of the most appropriate input, chunking the input into manageable and useful segments, developing support material for self access learning and training of learners in the best uses of this input is ever more important.

The three most popular uses of the Internet for language teaching are electronic mail (email), the World Wide Web, and Multiple-user-domains Object Oriented (MOOs). Numerous programs exist for using electronic mail. Using e-mail, students can receive effective feedback. The teacher is able to respond to requests from students and examine their work in progress. E-mail feedback makes it possible for a teacher to develop ideas, both collectively and individually and ask better questions and at the same time provide examples and offer remarks. There is a large and increasing amount of educational material on the Web provided by universities worldwide to support online courses and degree programs. For autonomous language learners interested in improving their listening comprehension, the Internet now provides a diversity of audio sources comparable to what is available in text. In a guide to using computers in language teaching, Szendeffy (2005) argues that computers provide students and teachers with great access and integration of material than tape recorders or videocassettes. "Having examined the available sources on developing learners ${ }^{\text {ee }}$ listening skills in language classes, it is easier to understand why Internet audio has suddenly become popular now" ( Kavaliauskien ,2008)

Teachers can also modify and adopt any CALL learning materials and create relaxed atmosphere for learning, as a result, to suite the learnersee needs and levels of competence. While using the CALL materials learners have the autonomy to identify and adopt the kind of strategy that would best suit their learning style and choosing such a strategy would also facilitate the learning process. Boster, Meyer, Roberto,and Inge, (2002) cites studies of teacher beliefs that multimedia presentations help increase interest, attention and curiosity. Teachers believed this increased attention led to increased retention and motivation, which ultimately led to better learning and improvement in student grades. 
The second factor which is involved to this research is anxiety. Second language learning coming along with a particularly anxiety-provoking experience has several reasons. First, Young (1999) argued that when students are asked to deliver their thoughts or idea with a foreign language in which they have limited competence, their performance can be very threatening to their selfimage. According to Horwitz et al. (1986) "performance in the L2 is likely to challenge an individual's self-concept as a competent communicator" and this might lead to "reticence, selfconsciousness, fear or even panic." In accordance with this position, communication apprehension has been reveal to affect one's willingness to communicate in the L2(MacIntyre \& Charos, 1996; Yashima, 2002, Yashima, et al., 2004).

Secondly, Scovel (1978) states the affective factors deal with the emotional reactions and motivations of the learner as conducting the study on the effect of affective factors on language learning. He claims that one of the most affective variables in learning tasks is anxiety. Moreover, Scovel (1978) and Young (1991) agree that too much anxiety can have a debilitating effect on language learning. The facilitating or debilitating aspect of anxiety is difficult to measure in the language learner.

Horwitz et al. (1986) listed three elements of foreign language anxiety: (1) communication apprehension, (2) fear of negative evaluation, and (3) test anxiety. Communication apprehension results from the fear of the real or expected interactions with others. Fear of negative evaluation arises when a learners' need to make a positive social impression on others leads to a despondent mood. Test anxiety results from the experience of failure. Here the level of anxiety is proportionate to the excessive memory that accompanies the experience of failure (Aida, 1994). According to Horwitz and Young (1991), there are two classifications to explain language anxiety: (1) language anxiety may be the result of more general types of anxiety, such as test anxiety or the communication apprehension found in shy people; or (2) language anxiety may be a specific response to language learning. Thus factors unique to langue learning cause some people to be nervous. To sum up, anxiety contributes to the affective filter of Kranhen's Monitor Model.

\section{Statement of the problem and purpose of the study}

According to Pintrich (2000) the categories of learning are interrelated and interact with one another. When learners resort to control and regulation strategies, they have a better control over their attention, motivation, affect, behavior, and self instruction. The 
e- Learning encourages learners to work independently as each student can work on different tasks with the "integrated learning environment" (Wu et al., 2012). In other words, it addresses differentiation and it allows students to work according to their own pace. Advanced learners could thus be able to work faster and finish more activities than novice learners (Nedeva \& Dimova, 2010). This makes students keep their personal schedules as they work at their own place and according to their own preferences. It also improves students' language skills as they practice reading, listening, speaking and writing via the different e-learning resources and tasks.

\section{Significance and Justification of the study}

Internet-based distance learning, by its very nature has the potential to affect language learning because it radically changes the learning environment offered by physically separating the instructor from the leaner. It seems that identifying the extent to which students utilize selfregulatory behaviors in internet-based distance learning will provide a valuable insight for the design and delivery of e-Learning courses. Additionally, a comparison of the first-stage and endstage of the learners exposed to the e-Learning program may lead to an improved understanding of learners.

The information obtained from this study may be utilized to design and develop more effective eLearning courses and provide practical information for educators and instructional designers.

\section{RESEARCH QUESTION AND HYPOTHESIS}

This study aims at investigating the implementation of e-learning constructive role plays on Iranian EFL learners' language learning in university classes. To achieve this, the present study addresses the following research questions:

- Does e- learning have any effect on improving Iranian EFL learners' language Skills?

- Does e- learning decrease Iranian EFL learners' language learning anxiety?

\section{METHODOLOGY}

\section{Participants}

This sample consists of both male and female undergraduate junior EFL university students majoring in computer engineering and IT (information technology), the participants were 120 Iranian ESP students. Since the participants formed intact groups, a preliminary English Test (PET) was administered to all students to assess their general proficiency and 30 test takers who 
obtained a score range of 60-70 were selected to form the research participants. The participants were further randomly assigned as the control group who were taught using traditional methods of teaching with no multimedia laboratory and the experimental group who attended multimedia language laboratory where a personal computer was available for each participant.

\section{Instrumentation}

One questionnaire and two tests were used in this study. A preliminary English Test (PET) was administered to all students, pre-test and post-test to assess their general proficiency. The questionnaire was composed of three parts. The first part of the questionnaire elicits basic demographic information, including gender and year in school. The second part of the questionnaire reproduces the Foreign Language Classroom Anxiety Scale (FLCAS) that was designed by Horwitz, Horwitz, and Copes (1986). This part consists of 33 statements. The last part of this survey investigates students' perception of learning English in a multimedia environment. This part consists of 20 questions. For all but one of the questions in the third section, respondents are asked to rank their agreement with a statement on a 5-point Likert scale. Question 20 of part three is an open-ended question.

\section{Procedure}

To begin with, the English classroom used by the subjects of this research was equipped with multimedia and computer equipment. During one semester, multimedia instruction, such as video watching, online English exercises, and power point file presentations, were delivered and presented in English class. A preliminary English Test (PET) ,pre-test and post-test, were administered to all students to assess their general proficiency and 30 test takers who obtained a score range of 60-70 were selected to form the research participants. The participants were further randomly assigned as the control group who were taught using traditional methods of teaching with no multimedia laboratory and the experimental group who attended multimedia language laboratory where a personal computer was available for each participant.

The syllabus was the same for two groups and used the same instrument which is usual in language laboratories, except that control group did not use computer. The experimental group participants were sent extra listening and reading comprehension files through their emails and could have more listening and reading activities. They had to write down the answers and sent them back to the teacher through an e-mail. For sixteen weeks, the participants in the experimental group received twelve listening and reading comprehension tasks. They were 
required to return their answers within a two days interval recorded by the researcher in feedback report sheet which were designed by the researcher to record the students ${ }^{\mathrm{ce}}$ answers. The tasks were chosen from New Interchange series volume one (Richards, 1998) along with the supplementary materials, workbook, audio and tests (i.e., placement and final tests). The lessons were presented in an interactive mode to the students on the internet through a site. The text and audio parts of the tasks were compiled by Word 2003, 2007 as Word files and were sent to the participants. At the end, the listening and reading comprehension post-test was administered to both groups in order to observe the probable impact of CALL on the participants "e listening and reading comprehension skills.

At the end of the semester, students were asked to fill out the questionnaire. It took about 40 minutes to complete and was administered during the students' regular English class.

\section{RESULTS AND DISCUSSION}

This study explores the effect of e- learning on the Iranian EFL learners' language Skills. To achieve this goal, the following research questions were raised;

- Does e- learning have any effect on improving Iranian EFL learners' language Skills?

- Does e- learning decrease Iranian EFL learners' language learning anxiety?

The data were analyzed through analysis of covariance which has four main assumptions; normality, homogeneity of variances, linear relationship between the dependent variable (posttest) and the covariate (pretest) and homogeneity of variances.

The present data enjoyed normal distribution. As shown in Table 1, the ratios of skewness and kurtosis over the standard errors were lower than the absolute value of 1.96.

Table 1. Descriptive Statistics; Testing Normality Assumption

\begin{tabular}{lcccccc}
\hline & & $\mathrm{N}$ & \multicolumn{3}{c}{ Skewness } & \multicolumn{3}{c}{ Kurtosis } \\
\cline { 3 - 7 } Group & & \multicolumn{3}{c}{ StatisticStatisticStd. ErrorRatioStatisticStd. ErrorRatio } \\
\hline \multirow{2}{*}{ Experimental } & Pretest 30 & -.181 & .398 & $-0.45-.333$ & .778 & -0.43 \\
& Posttest30 & -.059 & .398 & $-0.15-.784$ & .778 & -1.01 \\
\hline \multirow{2}{*}{ Control } & Pretest 30 & -.422 & .398 & $-1.06-.801$ & .778 & -1.03 \\
& Posttest30 & -.297 & .398 & $-0.75-.719$ & .778 & -0.92 \\
\hline
\end{tabular}


The assumption of homogeneity of variances was also met. The results of the Levene's test $($ Table 2$)(F(1,68)=1.16, p=.285)$ rejected the null-hypothesis that the groups did not enjoy homogenous variances.

Table 2. Levine's Test of Equality of Error Variances

\begin{tabular}{llll}
\hline $\mathrm{F}$ & df1 & df2 & Sig. \\
\hline 1.160 & 1 & 68 & .285 \\
\hline
\end{tabular}

The relationship between the dependent variable (posttest) and the covariate (pretest) was linear. As displayed in Table 3, the results of the linearity test $(\mathrm{F}(1,50)=121.82, \mathrm{p}=.000)$ rejected the null-hypothesis that the relationship between dependent variable and the covariate was not linear.

Table 3. Testing Linearity Assumption

\begin{tabular}{|c|c|c|c|c|c|c|}
\hline & & & $\begin{array}{l}\text { Sum } \\
\text { Squares }\end{array}$ & $\begin{array}{l}\text { of } \\
\text { df } \\
\text { Square }\end{array}$ & $\mathrm{F}$ & Sig. \\
\hline \multirow{5}{*}{$\begin{array}{l}\text { Posttest } \\
\text { Pretest }\end{array}$} & \multirow{3}{*}{$\begin{array}{l}\text { Between } \\
\text { Groups }\end{array}$} & (Combined) & 461.777 & 1924.304 & 7.087 & .000 \\
\hline & & & \multirow{2}{*}{$\begin{array}{l}417.788 \\
\text { from } \\
43.989\end{array}$} & 1417.788 & \multicolumn{2}{|c|}{121.826 .000} \\
\hline & & $\begin{array}{l}\text { Deviation } \\
\text { Linearity }\end{array}$ & & 182.444 & .713 & .782 \\
\hline & \multicolumn{2}{|c|}{ Within Groups } & 171.470 & 503.429 & & \\
\hline & \multicolumn{2}{|l|}{ Total } & 633.246 & 69 & & \\
\hline
\end{tabular}

The probability associated with the interaction between groups and the covariate was not significant $(\mathrm{F}(1,66)=1.25, \mathrm{p}=.266)$ (Table 4). Thus it can be claimed that the assumption of homogeneity of regression slopes was retained. 
Table 4. Testing Homogeneity of Regression Slopes

\begin{tabular}{llllll}
\hline \multirow{2}{*}{ Source } & \multicolumn{2}{l}{ Type III Sum } \\
& of Squares & Df & Mean Square & F & Sig. \\
\hline Group & 12.271 & 1 & 12.271 & 16.925 & .000 \\
Pretest & 417.070 & 1 & 417.070 & 575.235 & .000 \\
Group * Pretest & .911 & 1 & .911 & 1.256 & .266 \\
Error & 47.853 & 66 & .725 & & \\
Total & 15365.250 & 70 & & & \\
\hline
\end{tabular}

As shown in Table 5, the experimental group $(\mathrm{M}=16.05, \mathrm{SE}=.14,95 \% \mathrm{CI}[15.76,16.33])$ had a higher mean on the posttest of PET than the control group $(\mathrm{M}=12.96, \mathrm{SE}=.14,95 \% \mathrm{CI}$ $[12.67,13.25])$ after controlling for the possible effect of their entry general comprehension ability as measured through the pretest.

Table 5. Descriptive Statistics; Posttest of General Proficiency by

Group (Controlling for Pretest)

\begin{tabular}{lllll}
\hline \multirow{2}{*}{ Group } & \multirow{2}{*}{ Mean } & Std. Error & \multicolumn{2}{l}{$95 \%$ Confidence Interval } \\
\cline { 4 - 5 } & & & Lower Bound & Upper Bound \\
\hline Experimental & 16.950 & .144 & 15.762 & 16.338 \\
Control & 13.064 & .144 & 12.676 & 13.252 \\
\hline
\end{tabular}

Based on the result displayed in Table $6\left(\mathrm{~F}(1,67)=229.03, \mathrm{p}=.000\right.$, Partial $\eta^{2}=.774$, representing a large effect size) it can be claimed that there was a significant difference between the experimental and control groups' means on the posttest after controlling for their performance on the pretest. Thus the null-hypothesis was rejected. 
Table 6. Tests of Between-Subjects Effects; Posttest of General Proficiency by Group (Controlling for Pretest)

\begin{tabular}{llllllll}
\hline \multirow{2}{*}{ Source } & \multicolumn{2}{l}{$\begin{array}{l}\text { Type III Sum } \\
\text { of Squares }\end{array}$} & df & Mean Square & & Sig. & $\begin{array}{l}\text { Partial } \\
\text { Squared }\end{array}$ \\
\hline Pretest & 416.308 & 1 & 416.308 & 572.000 & .000 & .895 \\
Group & 166.695 & 1 & 166.695 & 229.036 & .000 & .774 \\
Error & 48.763 & 67 & .728 & & & \\
Total & 15365.250 & 70 & & & & \\
\hline
\end{tabular}

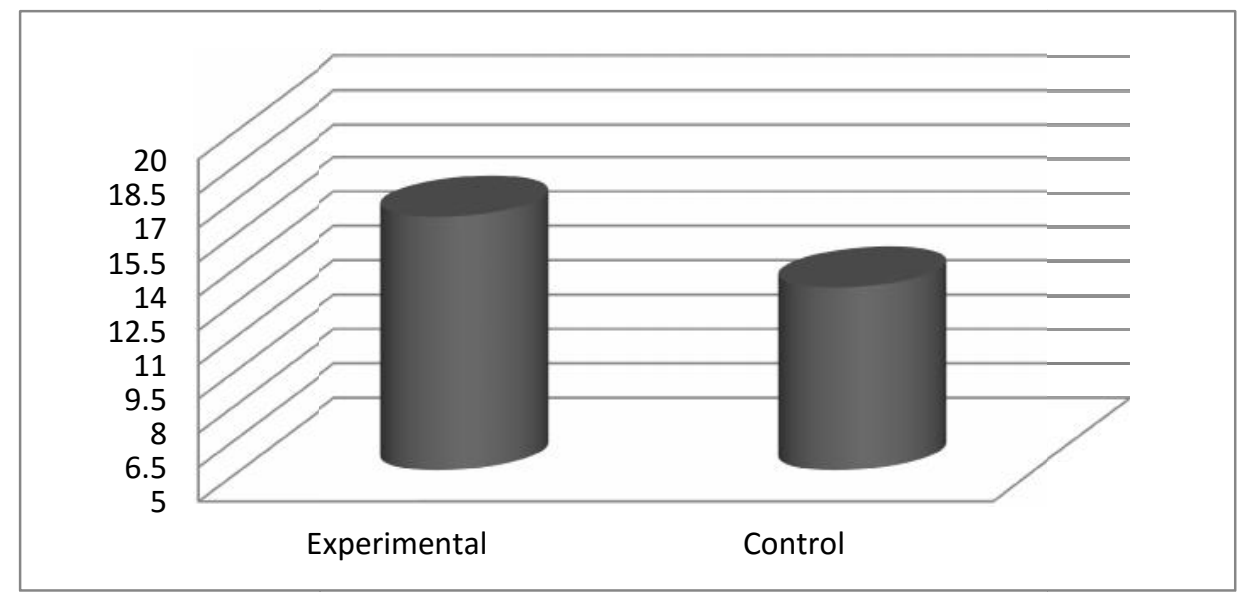

Fig.1. Mean scores on posttest of general proficiency by groups after controlling for pretest

With regard to the second research question, at the end of the semester, students were asked to fill out the questionnaire and the result shows that $86 \%$ of students said they enjoy learning English through e-learning. In class, all students should have access to multimedia equipment so that they don't need to face the teacher directly. Some students may feel nervous when they are learning a foreign language. Therefore, using multimedia teaching may reduce some students' learning anxiety. Multimedia teaching methods emphasize the fact that the best form of interaction between the teacher and the student is unlike the traditional one-way teaching method. In an electronic environment, it is much easier to create multimedia teaching settings that develop collaborative skills and interaction, and reduce the learner's level of anxiety. 
The results are also consistent with the findings of John and Torrez (2001) who have emphasized the possibilities for second language learning offered by new technological devices. The findings are also in line with the findings of Sivin-Kachala and Bialo (2000) whose research findings revealed positive and consistent patterns of effectiveness of technology when students were engaged in teaching environments.

\section{CONCLUSION}

E-learning is an essential tool that should be used to supplement the EFL face-to-face classes. It includes various activities and resources that if used by the students and monitored by the teacher could enhance the students' language proficiency. As the world progresses, we need to utilize technology and to synchronize ourselves with it. The present study reveals that multimedia environments have a positive impact on language learning for EFL students in Iran. The results of the study indicate that the participants believe that the best way to learn English is through computer-assisted learning environments. The findings of this study claim that English instructors can be more aware of students' psychological needs during the process of language acquisition. Moreover, they should provide proper multimedia instruction in the class in order to help overcome students' foreign language learning anxiety.

Based on the results and discussion from the pretest scores, post-test scores, and student questionnaires, it can be concluded that e-learning role plays have positive effects on improving the students at various language proficiency levels. Students performed well and they applied the knowledge gained from the tutorial class and from their previous studies to perform the constructive e-learning role plays actively and successfully. Furthermore, most of the students expressed positive opinions towards the implementation of e-learning constructive role plays in classes. Scaffolding and instruction on how to carry out e-learning role plays are essential and necessary because scaffolding helps students understand the tasks better before they start the role plays. Students enthusiastically apply as much knowledge as possible from their previous studies to construct new knowledge. Students actively explore the knowledge instead of passively accepting it.

\section{LIMITATION AND DELIMITATIONS OF THE STUDY}


Researcher selected the sample concerned only with the following; the conclusions will not be extended beyond it.

1- The study is delimited to Iranian ESP learners

2- The study is delimited to junior ESP learners at BA level

3- The study is delimited to Iranian universities

\section{REFERENCES}

[1] Aida, Y. (1994). Examination of Horwitz, Horwitz, \& Copes' construct of foreign language anxiety: The case of students of Japanese. The Modern Language Journal, 78, 155-168.

[2] Birch (2002). English L2 Reading; Getting to the bottom. Reviewed by; Steven Brown, Youngstown State University

[3] Boster, F.J., Meyer, G.S., Roberto, A.J. \& Inge, C.C. (2002). A Report on the effect of the united streaming application on educational performance. Retrieved November 28, 2011, from United Learning, Discovery Education at: http://www.unitedlearning.com/images/ streaming/evaluation.pdf.

[4] Carter, R., Nunan, D. (2002). The Cambridge guide to teaching English to speakers of other languages. United Kingdom: Cambridge University Press.

[5] Diaz, D. P. and Cartnal, R. B. (1999). Students' learning styles in two classes. College Teaching, 47 (4), 130-136.

[6] Dick \& Carey, ( 1996). The Systematic Design of Instruction.University of South Florida

[7] European Commission (2001). The E-Learning Action Plan: Designing Tomorrow's Education (p. 20), Brussels.

[8] Gagne, Briggs \& Wager (1992). Gagne's Nine Events of Instruction. Northern Illinois University, Faculty Development and Instructional Design Center

[9] Garrison, D. R., \& Vaughan, N. D. (2008). Blended Learning in Higher Education: Framework, Principles, and Guidelines. Booksgooglecom, 1, 272.

[10]Horton, W. (2006). E-Learning by Design. Hoboken, NJ: Wiley Publishing, Inc.

[11]Horwitz, E. K., Horwitz, M. B., \& Copes, J., (1986). Foreign language classroom anxiety. Modern Language Journal, 70, 125-132.

[12]Horwitz and Young (1991). The role of the Teacher in Alleviating Anxiety in Language Classes. International Research Journal of Applied and Basic Sciences.Vol 4 
[13]Hwang, Y. L., \& Huang, P. W. (2010). A study of EFL college students' language anxiety in multimedia environments. The International Journal of the Humanities. 8(2), 367-378.

[14]Johns, K. M., \& Tórrez, N. M. (2001). Helping ESL learners succeed. Phi Delta Kappa, 484, 749.

[15]Kavaliauskien , G. (2008). Podcasting: A tool for improving listening skills. Teaching English with Technology. Vol 8, issue 4. http://www.tewtjournal.org

[16]Lai, C. (2006) the advantages and disadvantages of computer technology in second language Acquisition. National Journal for Publishing and Mentoring Doctoral Student Research. 3 (1), 1-6.

[17] MacIntyre, P. D. \& Charos, C., (1996). Personality, attitudes, and affect as predictors of second language communication. Journal of Language and Social Psychology. 15, 3-26.

[18] Nakayama et al., (2006). The impact of learner characteristics on learning performance in hybrid courses. The Electronic Journal

[19]Nedeva, V. and Dimova, E. (2010). Some Advantages of E-Learning in English Language. Trakia Journal of Sciences, 8. Waterhouse, S. (2003). The Power of E-Learning the Past, the Present, and the Future.

[20]http://ritim.cba.uri.edu/wp2003/pdf_format/Wiley-Encycl-Internet-Diffusion-v12.pdf

[21]Pintrich, P. R. (2000). The role of goal orientation in self-regulated learning in M. Boekaerts, P. R. Pintrich \& M. Zeidner (Eds.), Handbook of selfregulation (451-502), San Diego, CA: Academic Press.

[22]Rosenberg, M. J. (2001). E-Learning: Strategies for Delivering Knowledge in the Digital Age. New York: McGraw-Hill.

[23]http://findarticles.com/p/articles/mi_7587/is_200910/ai_n42041564/?tag=content;col1

[24] Scovel, T. (1978). The effect of affect on foreign language learning: A review of the anxiety research. Language Learning, 28, 128-142.

[25] Sivin-Kachala, J. \& Bialo, E. (2000). 2000 research report on the effectiveness of technology in schools (7th Ed.). Washington,DC: Software and Information Industry Association.

[26]Szendeffy, J. (2005). A Practical Guide to Using Computers in Language Teaching. Ann Arbor: University of Michigan Press.

[27]Terrell \& Dringus (2000). An investigation of the effect of learning style on student success in an online learning environment. Journal of Educational Technology System,28(3),231-238 
[28]Waterhouse, S. (2003). The Power of E-Learning the Past, the Present, and the Future.

[29] http://ritim.cba.uri.edu/wp2003/pdf_format/Wiley-Encycl-Internet-Diffusion-v12.pdf

[30]Wojciechowski \& Palmer (2005). Individual student characteristics. Online Journal of Distance Learning Administration.8 (2) Retrieved April 14,2006

[31]Wu, B., Xu, W., \& Ge, J. (2012). Experience Effect in E-Learning Research. SciVerse Science Direct. Procedia, 24, 2067- 2074. www.sciencedirect.com

[32] Yashima, T. (2002). Willingness to communicate in L2: The Japanese EFL context. Modern Language Journal, 86, 54-66

[33] Yashima, T., Zenuk-Nishide, L., \& Shimizu, K. (2004). The Influence of attitudes and affect on willingness to communicate and second langue communication. Language Learning, 54, 119-152.

[34] Young, D. J. (1991). Creating a low-anxiety classroom environment: What does language anxiety research suggest? Modern Language Journal, 75, 426-437.

[35]Zhang \& Sternberg (2001). Perspectives on Thinking, learning, and Cognitive Styles. International Review of Education vol; 48, Issue 6

\section{How to cite this article:}

Jahansouz Shahi M. A. The impact of E-learning on improving Iranian EFL learners' language skills: decreasing learning anxiety. J. Fundam. Appl. Sci., 2016, 8(3S), 261-275. 